\title{
The archaeology of the military orders: the material culture of holy war
}

Article

Accepted Version

Pluskowski, A. (2018) The archaeology of the military orders: the material culture of holy war. Medieval Archaeology, 62 (1). pp. 105-134. ISSN 0076-6097 doi:

https://doi.org/10.1080/00766097.2018.1451590 Available at https://centaur.reading.ac.uk/76372/

It is advisable to refer to the publisher's version if you intend to cite from the work. See Guidance on citing.

To link to this article DOI: http://dx.doi.org/10.1080/00766097.2018.1451590

Publisher: Maney Publishing

All outputs in CentAUR are protected by Intellectual Property Rights law, including copyright law. Copyright and IPR is retained by the creators or other copyright holders. Terms and conditions for use of this material are defined in the End User Agreement.

\section{www.reading.ac.uk/centaur}

\section{CentAUR}

Central Archive at the University of Reading

Reading's research outputs online 
The Archaeology of the Military Orders: The Material Culture of Holy War By ALEKS PLUSKOWSKI ${ }^{1}$

THIS PAPER reviews the current state of research into the archaeology of the military orders. It contrasts the advances made by historians and archaeologists, with the latter continuing to focus on the particularism of individual sites, with an emphasis on architectural analyses. Historians have contributed new insights by adopting a supranational approach. This paper argues that archaeologists can build on this by adopting a more problem-oriented, comparative approach. Drawing on examples from frontier and heartland territories, archaeological approaches are subdivided into material investment, material identity and cultural landscapes, to place sites of the military orders within a long-term, multi-scalar contexts. This contributes to a broader social and economic understanding of the orders, who contributed significantly to urbanisation, rural development and trade, and invested in material expressions of their authority and ideology. The paper concludes that more holistic, inter-regional approaches will move the archaeological study of the military orders forward.

The religious military orders are, without doubt, one of the most distinctive and truly international institutions of the Middle Ages. Officially established with the Templars in AD 1120 , they created a new social category of warriors-professed-religious, albeit one with earlier conceptual precedents. ${ }^{2}$ The orders came to define the crusading movement both as permanent garrisons in the frontiers of Latin Christendom, and as procurers of people, finances and goods within the heartlands of Europe in order to maintain these garrisons. ${ }^{3}$ Their roles varied between regions, orders, and over time, but their institutionalised fusion of corporate monasticism with military professionalism made them unique. Moreover, their control of territories in the eastern Mediterranean, the Baltic and Iberia defined crusading frontiers with opposing societies that endured for several centuries. ${ }^{4}$

The boom in crusader studies in recent decades has renewed positive interest in the military orders. ${ }^{5}$ Crusading imagery had been promoted by 19th-century western elites in attempts to 're-masculinise Christianity', ${ }^{6}$ but negative perceptions of the military orders, in particular the Templars, reflected contemporary concerns over religious violence merging with Orientalism. ${ }^{7}$ This stereotype, harking back to 13th-century criticism of the order, has been superseded by the image of the Templars as bearers of occult knowledge, who survived their suppression in 1312, went 'underground' and continued to pass down their 'secrets' into the modern day. ${ }^{8}$ This perception of the order is ultimately derived from the link made between freemasonry and crusading (and particularly the Templars) from the 18th century. ${ }^{9}$ The Hospitallers have never attracted such an alternative historiography, almost certainly due to their enduring association with social welfare (through, for example, the St John Ambulance). Indeed, they have been presented as a useful model for contemporary altruism. ${ }^{10}$

The Teutonic Order remains controversial in eastern Baltic countries, particularly in Poland, but for very different reasons. ${ }^{11}$ Here, it has been the focus of nationalist stereotyping, reflecting an antagonistic relationship that was heightened in the 14th century, amplified in the 15th century and revived within the resurgent nationalism of the later 19thand early 20th centuries. For some, Henryk Sienkiewicz's Krzyżacy (translated as 'Knights of the Cross' or 'Teutonic Knights' and published in 1900) is comparable to Walter Scott's Ivanhoe (1820) - the first appearance of the villainous Templars in popular fiction - but for many it remains one of the great works of Polish literature and an essential part of the 
school curriculum. In Communist-era Poland, history textbooks from elementary level upwards emphasised the negative qualities of the Teutonic Order and the development of their domains as an early expression of German imperialism. ${ }^{12}$ The designation of the iconic headquarters of the Teutonic Order, Malbork Castle (formerly Marienburg), as a UNESCO World Heritage Site in 1997, and the image of the Order promoted by the Castle Museum at Malbork, have acted as counterweights to nationalist narratives and contributed to a growing international awareness of the Order's achievements, although not without controversy (Fig 1). ${ }^{13}$ When in 2010, the centenary of the Battle of Grunwald (aka Tannenberg) provided an opportunity to reaffirm nationalist stereotypes, it was taken up with great enthusiasm. ${ }^{14}$

The numerous Iberian military orders, which enjoyed support throughout the Middle Ages, were brought completely under royal control with papal approval in 1523 in CastileAragon and 1551 in Portugal. At this point they were re-cast as prestigious landowners and upholders of regional traditions. They also held important administrative positions for the Crown, enduring until the 19th century. ${ }^{15}$ For this reason, and because of their integral association with the nationalist narrative of the unification of Spain and Portugal's overseas expansionism, they have attracted the least controversy of all the medieval military orders. There has been limited interest in the Iberian military orders compared to other regions of Europe, ${ }^{16}$ with most studies focusing on the particularities of individual orders. ${ }^{17}$ In recent years the situation has begun to change, ${ }^{18}$ and the heritage of the orders is also receiving wider recognition. ${ }^{19}$

The military orders are of current and widespread public interest, and in some European countries they continue to feature in nationalist polemics, ${ }^{20}$ a point that has not been lost on historians. Indeed, the Crusades, in general, have become a visibly accessible interface between the academic and public domains. It is therefore surprising that more archaeologists have not matched the efforts of historians. At the heart of this disparity lies a striking contrast between historical and archaeological research. The archaeological contribution lacks coherence when compared to the achievements of historical scholarship on the military orders, particularly the intensity of research stimulated by Jonathan RileySmith's establishment of the 'Pluralist School' of crusader studies in the late 1970s. This has also led some historians to question the value of archaeological data, which has been viewed as overly descriptive and particularistic. This paper is written for both archaeologists and historians, with the aim of assessing the disparity between historical and archaeological studies of this fundamental medieval institution, and proposing a way forward.

\section{CATCHING UP WITH HISTORICAL RESEARCH}

The military orders, as a specific topic of research, have been embraced by modern crusader studies, for more than any other group they embodied the crusading movement of the 'long' Middle Ages. Since their scholarly rehabilitation in the mid-1970s, ${ }^{21}$ the military orders have been the subject of both synthetic works and individual studies, ${ }^{22}$ with broader themes emerging from the publications of regular conference series held in Torun and Clerkenwell. Hunyadi and Laszlovszky's 2001 volume, based on a previous conference in Budapest was the first to bring together scholarship from Western and Eastern Europe. Taken together, they represent a sustained research horizon, of which the principal achievement has been to highlight the diversity of roles attributed to the military orders. 
These roles transcended the provisioning of military resources and supplies to the frontier, to include the extensive provision of welfare, ${ }^{23}$ diplomacy with evidence of significant political agency, ${ }^{24}$ complex economic and bureaucratic structures, including the famous banking system of the Templars, ${ }^{25}$ involvement in trade, maritime networks, and urban life. ${ }^{26}$ All these themes are interconnected. Indeed, the development of the military orders has been linked to the process of urbanisation, in terms of their networks, recruitment and infrastructure. ${ }^{27}$ The role of women has also been examined for many of the military orders, ${ }^{28}$ as has the spirituality of individual orders, ${ }^{29}$ as 'professed religious' ${ }^{30}$ The internationalisation of research on military order and crusader history in the last two decades, ${ }^{31}$ has made it possible to identify how much regional variation there was within the orders, despite their supranational hierarchical structures, from financial matters to liturgical praxes. ${ }^{32}$ At the same time, the largest military orders appear to have followed similar trajectories in their institutional behaviour. ${ }^{33}$ Direct obedience to the papacy was, in practice, diluted by varying levels of control exerted by kings and other magnates, and the main orders were never deployed in the papal war on heresy. Royal influence was strongest in Iberia, where military orders were effectively 'territorialised'. Moreover, regular comparisons are made between the houses of the orders within Europe and at the frontiers; historians understand these as functioning supranational institutions with implications for their organisation and character. Military orders within the same regions have also been compared, both within Europe and at the frontier, ${ }^{34}$ whilst detailed regional surveys of individual orders remain a popular focus of historical enquiry. ${ }^{35}$ Whilst the orders have united the study of different crusading frontiers promoted by the pluralist school, they also exemplify more general problems in the discourse on the coherence of crusading. ${ }^{36}$

Historians have also been following archaeological research, but cite it sparingly. Castles and urban compounds, particularly the Hospitaller complex in Acre, are used more illustratively than analytically. Helen Nicholson's overview of the Templars is studded with references to archaeological sites and standing monuments. ${ }^{37}$ David Marcombe's characterisation of Burton Lazars as a preceptory of the Order of St Lazarus, rather than a leper hospital, surveys the fragmentary and problematic archaeological record of the site but relies more on historical data for this interpretation. ${ }^{38}$ In contrast, Anthony Luttrell described the lack of effective historical research for the publication of the Clerkenwell excavations as a 'disappointing failure'; 39 being the best known provincial headquarters of a military order in western Europe from an archaeological perspective. ${ }^{40}$ Whilst archaeologists do, routinely, include written sources within their studies, there are few examples where both groups have worked together on the military orders. Exceptions include the most recent study of the New Temple complex in London and a survey of art under the Teutonic Order's rule in Prussia, both the results of multidisciplinary conferences. ${ }^{41}$ Indeed, Luttrell went on to question whether an archaeology of the military orders even exists. ${ }^{42}$ This is despite Adrian Boas' seminal work Archaeology of the Military Orders, which brought together all the categories of archaeological data for the military orders in the Latin East. ${ }^{43}$ Why has the archaeological contribution failed to make a significant impression?

\section{THE FRONTIERS OF LATIN CHRISTENDOM \\ ARCHAEOLOGIES OF THE MILITARY ORDERS \\ In regions which were once crusading frontiers, there has been sustained archaeological investigation of the sites of the military orders for over a century. Adrian Boas' Crusader Archaeology, ${ }^{44}$ which made the archaeology of the Latin East accessible to}


international scholarship, was followed up in 2005 with his survey of the archaeology of the military orders in the Holy Land. Both syntheses drew upon a vast corpus of architectural and archaeological work. Given their involvement at all levels of Frankish society from the largest towns to the smallest manors, this arguably was - and remains - a principal component of the archaeology of the Latin East. In the eastern Baltic, it is a defining component of medieval archaeology. ${ }^{45}$ In Iberia, which had the greatest diversity of religious military orders of any region, there have been numerous excavations of castles, ${ }^{46}$ although rarely considered within a broader, comparative context. Exceptions include studies of the Upper Guadalquivir, the frontier between Christian Castile and Islamic Granada from the 13th century where the military orders represented the most important de facto Christian authority; their estates were the cultural landscapes of the Middle Ages. ${ }^{47}$

The Hospitallers likewise dominated the eastern Mediterranean islands from the end of the 13th century, investing in significant fortifications, and urban and rural infrastructure, ${ }^{48}$ although their dependence on financing from Western Europe prevented these from becoming a self-sufficient military order 'state'. ${ }^{49}$ The military orders were also deployed in more ephemeral frontier regions where traces of their activities are less tangible. For example, within the Pomeranian-Prussian frontier of the Lower Vistula the lesser known presence of the Hospitallers by the end of the 12th century and the Spanish Order of Calatrava in the early 13th century is only evident from documentary sources; their houses have not been identified archaeologically and their associated estates are difficult to reconstruct. ${ }^{50}$ In Transylvania, where the Teutonic Order operated for fifteen years with an intensity that alarmed the Hungarian nobility and prompted the brethren's expulsion, archaeologists have identified only one of the sites of their stone castles with confidence. ${ }^{51}$

Although the role of the military orders in the security of frontier regions is regularly highlighted and emphatically linked to their monumental fortifications, it is important to note that three of the major orders established in the Latin East started out as hospitals: the Order of St John, the Teutonic Order and the Order of St Lazarus. The provision of welfare, almsgiving and the construction of hospitals remained an important feature of these institutions. In fact, the militarisation of the Hospital prompted an internal crisis within the order in 1171 and welfare remained a dominant element throughout the 13th century. After 1309 , the order became even more involved in military activities which coloured how it was later perceived. ${ }^{52}$ Other, short-lived hospital orders, such as the xenon of St Sampson in Constantinople, were militarised within a crusading context, but retained a pronounced Hospitaller function. ${ }^{53}$ In the same way that hospitals were variably influenced by a monastic template, the communal lifestyle of a military order domus was facilitated by - and necessitated - a level of spatial integrity. In this respect, even the largest castles of the orders in the Latin East were more reminiscent of a monastery than a secular castle, with closely connected, shared interiors used by the entire community. Spatial analysis of these structures has reinforced how 'a religious lifestyle prevailed over all other activities'. ${ }^{54}$ In contrast to the baronial household, the day was punctuated by regular cycles of prayer, and communal meals were eaten in silence whilst passages of the Bible were read out. The apogee of the design reflecting this lifestyle can be seen in the regularity of the Teutonic Order's Konventsburgen constructed from the end of the 13th century, better understood as fortified monasteries than regular castles (Fig 2). ${ }^{55}$ That such structures continue to be popularly regarded as typical castles owes much to the restoration paradigms of the 19th and 20th centuries, which emphasised their militaristic rather than religious aspects. ${ }^{56}$ 


\section{LATIN EUROPE}

Although there had been earlier excavations on military order sites within Europe, the related archaeological themes were first set out when Roberta Gilchrist included the group within a volume on the material culture of religious women, hospitals and hermitages, incorporating the study of their European houses into the flourishing field of monastic archaeology. ${ }^{57}$ The monastic origin and character of the religious military orders particularly the formative influence of the Cistercians - had long been a subject of inquiry for historians, but this provided a framework for archaeologists to contextualise the sites and material culture of the orders. Material connections with monasticism were, and continue to be, drawn. The plain, almost stark, architecture of the Templars has long been thought to reflect Cistercian austerity, despite the lack of detailed comparative studies; ${ }^{58}$ both the Cistercians and Dominicans have been invoked as influences on the Teutonic Order's early brick buildings in Prussia. ${ }^{59}$ However, Gilchrist demonstrated how the design of preceptories, particularly in Britain, emulated the models of secular masculine institutions, more in common with baronial households than monasteries. ${ }^{60}$ Further down the scale of complexes associated with the military orders, an emphasis on religious spaces such as chapels within the camerae of the English Hospitallers and Templars, ${ }^{61}$ or the residences of procurators (German Pfleger; Latin Procuratoris) of the Teutonic Order, was not dissimilar to manorial or grange chapels (Fig 3). At this social level, the layout of the sites of the military orders becomes archaeologically indistinguishable from other estate centres. In contrast to the larger domus, these sites did not contain a full community of brethren, the lifestyle of the inhabitants was not punctuated with regular meetings of chapters, and this is reflected in their more flexible layout.

Gilchrist's survey also highlighted how few sites had been surveyed or excavated by the mid-1990s. This situation has not been significantly remedied. Knowledge of the urban houses of the orders, in any region of Europe, is largely dependent on the vicissitudes of developer-led rescue archaeology. The rural sites of the military orders, more suitable for research-led archaeology, had attracted relatively little attention. Twenty years later and the collection edited by Mathias Piana and Christer Carlsson, a series of case studies focusing on the three most important military orders, indicates that architectural studies continue to dominate the archaeology of military order sites in Europe and at the frontiers. ${ }^{62}$ Whilst some regions are now represented by large datasets that can be statistically analysed, others remain focused on 'type sites' and await more systematic research. Several important urban and rural sites have been excavated, along with their cemeteries, particularly in southern France. ${ }^{63}$ Some explanations for variability are clearly evident, such as the availability of building material and adaptations to local topography in Italy. ${ }^{64}$ Others are more complex, and relate to specific social and political contexts, highlighted by more focused studies of individual sites. The comparatively unusual levels of investment in the construction of the New Temple Church in London, which foreshadowed the use of Purbeck Marble as a highstatus building material in England, was not paralleled in other contemporary Templar houses in Western Europe. Moreover, the choice to rebuild the chancel in 1240 as a threeaisled rectangular structure was equally unique within the order (Fig 4). The peculiarities of the London Temple have been linked to the consistent involvement of kings and members of their courts in the late-12th and 13th centuries, and the choir may even have been intended as a potential tomb for Henry III. ${ }^{65}$ At the same time, very little is known about the archaeology of either early or later Templar precincts in London. Whilst there have been numerous watching briefs within this area, our knowledge of the multiple functions of the 
New Temple is based almost entirely on fragmentary written sources. ${ }^{66}$ In contrast, the subterranean remains of the Templar precinct in Paris are better known. Here, excavations in 2011, preceding renovation work of the Carreau du Temple, demonstrated a clear phase of expansion in the early 13th century, with the construction of claustral buildings, a new church and cemetery, and with adjoining land within the precinct used for cereal and vegetable cultivation. The complex became incorporated into the urban area of Paris following the expansion of the city walls which were completed by 1383 , but it retained a rural character. ${ }^{67}$

In terms of aspirational research directions, Piana and Carlsson's collection stressed the importance of landscape and holistic methodologies, whilst at the same time demonstrating that much of the basic archaeological groundwork documenting these sites remains to be done. This is true of all the European recruiting grounds of the military orders. Evelyn Lord's survey of Templar Houses in Britain and Ireland only lists the 32 sites which are still standing (and includes tentative and folkloric associations), whilst noting that 'Temple' features in 150 place names. ${ }^{68}$ South Witham, Lincolnshire, excavated in 1965-7, remains the best archaeologically known English Templar preceptory to date; ${ }^{69}$ the overwhelming majority continue to exist solely in the meta-world of charters, financial, and cartographic documents. In parts of Central and Eastern Europe, the archaeological identification of military order sites has been plagued by misunderstandings and mistakes. ${ }^{70}$ In Germany, the study of Teutonic Order sites continues to attract more attention from historians than archaeologists, and with important exceptions such as Marburg, ${ }^{71}$ the remnants of churches and chapels have been the principal foci of research, as also in the case of Templar (and later Hospitaller) sites such as at Bad Briesig near Cologne. In Scandinavia, the distribution of military order sites is known, but very few have been excavated; ${ }^{72}$ similarly, in the Netherlands. ${ }^{73}$ In France, archaeological investigations have been unevenly distributed across the country, and many reports remain inaccessible or unpublished. ${ }^{74}$ Finally, in Italy, the interrogations of the Templars produced an important collection of documents that has been critically used to reconstruct their organisation and lifestyle, ${ }^{75}$ but the military orders are poorly known from an archaeological perspective. Overall, the European archaeology of the military orders is fragmented and uneven, much like the written record. However, the latter is represented by more abundant information from a larger quantity of sites, which have been studied more intensively, synthetically and, most importantly, comparatively.

\section{TOWARDS AN ARCHAEOLOGY OF SUPRANATIONAL INSTITUTIONS DEDICATED TO HOLY WAR}

Stepping back, what is immediately noticeable is the traditionally narrow focus of archaeological research, along with a general absence of a clear research agenda and theoretical engagement. With the emphasis on the layout of individual sites, the archaeology of the military orders within Europe remains disconnected from their landscape context, estates, commercial and organisational networks and ultimately from the frontiers where resources were channelled. The connections between the frontiers and heartlands represented fundamental relationships of dependency that ensured the sustainability of the orders' crusading efforts. The records of the central Hospitaller convent in Britain point to constant interchange of personnel between East and West, ${ }^{76}$ whilst even the fragmentary records of the smaller Order of St Lazarus indicate the movement of men and resources to the Holy Land. ${ }^{77}$ The movement of personnel - and with them ideas - is of direct relevance for archaeologists, particularly relating to the homogeneity of material practices across 
orders, as well as shared approaches to building design, decoration, and visual expressions of corporate identity and ideology.

Art historians and architectural historians have led the way in emphasising more specific supra-regional connections in material culture. The widely discussed role of French artisans (especially from Provence) in decorating buildings in the Latin East has also been identified at the sites of the military orders. ${ }^{78}$ In the Baltic, the craftsmanship of artisans from Magdeburg has been identified in the earliest decorated portals of the Marienburg convent, ${ }^{79}$ whilst the leading role of a north French architect in the design of the New Temple Church in London has been linked to the regional and familial associations of English Templar provincial masters. ${ }^{80}$ The influence of monuments in the Holy Land on the design of some of the church naves of the military orders in the West is a popular truism, and remains one of the few tangible connections made between Western Europe and the Levantine frontier. The Holy Sepulchre was visually invoked in the churches of both the Old and New Temple in London, as well as the Hospitaller priory in Clerkenwell, whilst the octagonal Templar church nave in Metz, France, recalled the Templum Domini (Dome of the Rock) in Jerusalem. Equally striking are features which were not transmitted across the orders' networks from the Latin East, such as the bathing culture which had endured from Late Antiquity. This is best represented archaeologically at the Hospitaller castle at Margat, Syria, where five separate areas for bathing dating to the crusader period have been linked to the order's emphasis on welfare, combined with the pragmatics of hygiene in the climatic and bacteriological conditions of the Levant. ${ }^{81}$ No such structures were found at the Hospitaller provincial headquarters in London. Where site-based comparisons have been made, the focus has been on select monuments of individual orders, rather than the broader context which would include other military orders, as well as the full suite of monastic and secular sites. ${ }^{82}$

This situation is largely the product of the differing methodologies employed by archaeologists and historians. The latter bridge geographical distances far more easily by following the 'parchment trail', whilst archaeologists tend to focus on specific sites, sometimes macro-regions and more rarely work at the national level, and are only able to cross geopolitical borders with substantial funding, infrastructure and teams of diverse specialists. There are also historical and geopolitical reasons why archaeologists in, for example, the Levant or the Baltic countries have not readily worked together. Whilst this methodological divide is not easy to overcome, the potential contributions of archaeology to our understanding of the military orders can be subdivided into three themes: material investment, material identity, and cultural landscapes.

\section{CHARACTERISING THE RELATIVE MATERIAL INVESTMENTS OF THE MILITARY ORDERS}

The documentary record for the military orders is extremely variable. Most of the archives of the crusader states in the Latin East are lost, including those of the Templars, although the Hospitallers' central archive is by far the most complete. ${ }^{83}$ In the eastern Baltic, much of the archive of the Livonian branch of the Teutonic Order has been lost, in contrast to the documents for the Prussian branch which largely survive from the later fourteenth and 15th centuries. In Iberia, the preservation of documentary sources is also fragmentary; best known are the orders of Santiago and Calatrava, whilst the medieval archive of the Order of Alcántara has largely vanished. Archaeologists are therefore potentially well placed to contribute to the characterisation of individual properties belonging to the orders within the context of the long-term occupation of these sites, and in relation to other sites. This 
longue durée perspective enables individual occupation phases to be contextualised both temporally and spatially, and to assess the comparative impact of the orders in terms of material investment. When levels of investment are compared across sites, and in relation to other types of settlement, it is possible to assess their relative importance and function, including their ideological role.

Regional administrative centres received the most investment, but its extent and character was extremely variable. In the Latin East, the most striking changes in material investment following a transfer in ownership have been documented at Margat in Syria. When the Hospitallers obtained this from the Mazoirs in 1187, one of the leading baronial families in the principality of Antioch, the decision to transform the site into a major administrative centre saw a rapid programme of expansion which has been traced archaeologically. In addition to the fundamental spatial changes within the castle itself, this also resulted in the construction of a new fortified suburb of around ten hectares, tripling the size of the earlier settlement with corresponding urban material culture. ${ }^{84}$ Restoration of the castle, most likely following an earthquake in 1202, saw even more substantial investment in the communal spaces linked to the military order's requirements, such as the expanded chapter house. ${ }^{85}$ Material investment in urbanisation is a recurring theme in regions where the military orders wielded de facto power, from Templar Tartus in Syria and Hospitaller Rhodes at the edge of the Aegean through to the towns attached to the Teutonic Order's convents in the eastern Baltic. In all these cases, the lordship of the military orders was spatially articulated through the relationship with their adjacent towns - both integrated with the civic defences and segregated through internal systems of moats and walls, restricting accessibility and creating a visible sense of social zoning in the urban landscape (Fig 5).

The Teutonic Order's administrative centre in the Latin East at Montfort, Israel, was not subsequently occupied after the siege of 1271 , with virtually no physical evidence for any activity before the Order acquired the estate from the De Milly family in 1220 . Here, it has been possible to determine a substantial initial phase of investment followed by a second phase of repairs, perhaps after the earthquake documented in 1259, or the first Mamluk siege of $1266 .{ }^{86}$ This too, could be linked to the changing financial commitments of the Order, which were increasingly diluted by its conquests in the eastern Baltic with a contested focus on the Holy Land. ${ }^{87}$ The range of material culture recovered from the site indicates the brothers led a high-status lifestyle with access to imported glazed tableware, the use of stained glass designed by French glaziers and fine quality masonry, also visible in the material culture from their compound in Acre (Fig 6).

Further north, the excavated remnants of the stone wall encircling the hilltop in Feldioara in Transylvania, a fortification associated with the Teutonic Order's short-lived presence in the region (c 1211-1225), indicate a similar approach to the use of terrain where the irregular plan followed the shape of the outcrop. ${ }^{88}$ In contrast, the castra built by the Order in the eastern Baltic in the 13th-century shared little with their counterparts in the Levant, reflecting instead the regional use of timber and earth strongholds, and eventually the use of locally available building materials, namely field stones and brick. ${ }^{89}$ Early commandery centres in Prussia such as Thorn (Polish 'Torun'), Engelsburg (Polish 'Pokrzywno'), Christburg (Polish 'Dzierzgoń') and Graudenz (Polish 'Grudziądz') made use of local topography and were irregular in design; but from the last decades of the 13th century and throughout the 14th century the regular konventsburg form became typical in Prussia and was also found in Livonia. ${ }^{90}$ This standardisation was confined to the Order's domains in 
the eastern Baltic. Elsewhere, its houses were far from standardised; for example, its Italian properties remained virtually unmodified from their earlier forms. ${ }^{91}$

This standardisation parallels the development of the Teutonic Order's administrative structure in the eastern Baltic, ${ }^{92}$ and whilst there is an ongoing discussion about the various cultural influences on castle design, the Order evidently imposed its own template tailored to the ideological requirements of its core members. ${ }^{93}$ The regular (although not exclusive) reuse of the sites of earlier centres of authority, a direct product of the Order's military campaigns in the 13th century, also provided a sense of continuity with a clear expression of the transfer of power. The relative levels of investment in the Order's Baltic houses reflected its supra-regional hierarchy; the nuances of design express the agency of individual commanders and lesser officials along with the financial resources at their disposal. The translocation of the Order's administrative headquarters to Marienburg in 1309 prompted a substantial building programme which continued for over a century, resulting in a fortified conventual complex which came to enclose around 21 hectares by the first decade of the 15th century. Marienburg's expansion can be linked to the gradual accumulation of wealth following the creation of the Order's domains in Prussia and Livonia, and its major role in trade by the later 14 th century.

Whilst urban centres remained the most important consumers of imports, the relative representation of luxury material culture, especially imported table wares and building materials, contrast the purchasing power of the Order's convents from its smaller houses in the eastern Baltic, and all the houses of the Order from its subservient rural communities. This hierarchy is also visible in the variable exploitation of local environmental resources by the Order's houses, as well as access to imported foodstuffs. ${ }^{94}$ The Order's vassals are associated with comparatively diminutive sites; the small number of knightly families in Prussia and the few native vassals in Livonia permitted to maintain strongholds, invested in structures that were comparable to the lower end of the Order's hierarchy, as suggested by material traces of their continued occupation in the post-Crusade period. ${ }^{95}$ Instead, competitive social investment was focused on churches, where both urban and rural communities could sponsor the construction and decoration of substantial buildings to match those of the ruling theocracy. ${ }^{96}$ This brief sketch of the Teutonic Order's regional material investments highlights an important aspect of the governance of the military orders which is clearly visible when adopting a regionally comparative approach: that of local variability and adaptation within the framework of a hierarchical, supra-regional organisation.

\section{THE MATERIAL IDENTITY OF MILITARY ORDER COMMUNITIES}

In a society where status was expressed visually, the military orders were defined by their emblems - the red cross of the Templars, the green cross of the Lazarites and the monochrome of the Teutonic Order and Hospitallers, with the latter adopting plain white crosses on red surcoats and banners as battlefield garb in the 13th century. Penitential exclusion from the community of brethren was visually underlined by the deprivation of the cross as an identifying signum..$^{97}$ These visual signifiers of identity were specified in the rules of the orders, and were adopted around the same time as heraldic devices began to be used. If the military orders were visually defined by their clothing, the questions raised by historians relating to the degree of homogeneity and apparent diversity within the functioning of the military orders can also be directly addressed with material culture and practises, both at the level of individual sites and across their estates. 
Material expressions of identity are found in the decoration and structure of the order's houses, and in artefacts created for its members. A strong degree of standardisation might be expected from a hierarchical supra-regional institution with a clearly defined visual brand. The commonly shared unit of administration - the commandery (from the French commanderie; German Kommende; Latin praeceptoria [rendered in English as preceptor]) combined the 'functions of a residential space, an economic centre, a religious node, and a site of power'. ${ }^{98}$ Commanderies were places of 'interpenetration' between the secular and religious worlds, ${ }^{99}$ and in many respects the military orders can be understood as 'cultural intermediaries'. ${ }^{100}$ Whilst regional case studies have stressed the localised character of military order communities, as in the case of the Templars and Hospitallers in Occitania, ${ }^{101}$ the Teutonic Order in Italy, ${ }^{102}$ or the Templars in England, ${ }^{103}$ they would be identifiable by their associated decoration. Intermediate spaces in urban environments were most evidently focused on entrances; preceptories with enclosed precincts, such as the Hospitaller complex in Clerkwenwell or the Flemish Templar house in Slijpe, Belgium, were connected to their townscapes through monumental gatehouses. ${ }^{104}$ Specific designs of stone crosses, often carved in relief or painted, are widely interpreted as the insignia of the military orders' houses paralleling the clothing worn by the brethren, although many are no longer in situ; in particular the decorative use of the patté cross by the Templars is regularly cited and features in numerous site-specific surveys. Cross monuments were widely used in early and later medieval European society, but a systematic study of their use within the territories of the military orders remains to be conducted. In the eastern Baltic, the uses of crosses as boundary markers would have contributed to the creation of a new Christian landscape, whilst simultaneously reaffirming the authority of the Teutonic Order. ${ }^{105}$

The orders were not involved in the papal war on heresy, nor participated in missionary activity in multi-faith frontier regions, although they sponsored parochial infrastructure which contributed to the creation and consolidation of Christian landscapes. This has important implications for understanding their role within contested or subjugated communities. Here, the diverse households of military order sites could be reflected in material differences, with clothing, dress accessories and perhaps even tableware being actively used as markers of contrasting social identity. Such differences are noted amongst conquered Muslim communities in Iberia and native communities in the eastern Baltic. At the Teutonic Order's castle of Arrasch (Latvian 'Āraiši') in Livonia, the centre of an advocateship subservient to the nearby convent of Wenden (Latvian 'Cēsis'), excavations revealed that the extended household occupying the outer ward utilised indigenous building styles and jewellery, in contrast to the castle precinct where stone buildings were identified. ${ }^{106}$ These material differences are also found in other sites associated with the Order across Livonia, although they are comparatively less visible in Prussia. In Occitania, a region with numerous military order houses and estates, and whose heterodox communities were also the target of the Albigensian Crusade (1209-1229), the documented exhumation of heretics buried in military order cemeteries suggests that funerary archaeology potentially could shed new light on relationships within heterogeneous Christian communities. ${ }^{107}$

The infiltration of materialised elements of aristocratic identity is not surprising, given the emphasis on recruiting from the knightly classes, familial links with royalty, alongside the orders' role as territorial lords. Architectural decoration was used to communicate the prestige, power and aristocratic connections of the Teutonic Order in its European houses as well as on the Baltic frontier, particularly from the end of the 13th 
century. ${ }^{108}$ The increasingly secular character of some orders is also visible in Iberia. The reorganisation of Ambel in Aragon under the Templars following the Christian conquest in the 12th century saw the construction of a preceptory which included features found in the orders' other rural houses. This was established around a tower that had functioned as the local symbol of authority in the earlier Islamic polity, and a clear link to the crusading ideology of the conquest is evident with the establishment of a segregated Christian enclave. Substantial investment in the preceptory by the Hospitallers in the 14th century, including expansive fortifications, reflected the turbulence of nearby frontiers with other Christian states, rather than with the Nasrid Emirate located further south. This investment highlights the institution's regional territorialisation, also corresponding to visible changes in the lifestyle of the brethren. However, 16th-century graffiti at the site, commemorating military activities and most likely depicting the siege of Malta, indicate a visible expression of the crusading ideology which had been revived in Iberia in the later 15 th century. ${ }^{109}$ In Portugal, the contrast between the Templar house at Tomar and its successor belonging to the Order of Christ could not be starker, although the latter incorporated defining elements of the former, including the octagonal charola (Fig 7). The decorative schemes of the later convent twinned its religious ideology with the explicit support of the Crown, particularly the emblematic western façade of the conventual choir sponsored by Manuel I in c 1510-1513 (Fig 8). ${ }^{110}$

Aristocratic identity was also expressed in diet, a visual indicator of social status. Faunal assemblages from military orders' administrative centres are certainly comparable in character to those from secular high-status elite sites. ${ }^{111} \mathrm{~A}$ rare multidisciplinary study of the bodies of three grand masters of the Teutonic Order in the crypt of Kwidzyn (Poland; formerly Marienwerder in Prussia) Cathedral indicated a lifestyle comparable to high-ranking nobility, dating to the 15 th century when the Order had visibly lost its crusading mandate in the Baltic following the conversion of Lithuania to Catholicism and the subjugation of Samogitia. ${ }^{112}$ Both the burials and diets of brethren, alongside patterns of material-culture consumption, could also contribute to a largely unexplored aspect of the military orders their projections of masculinity. These appear to have been more aligned with the world of secular knighthood. For example, several (but not all) of the figural representations of the Teutonic Order's officials on funerary slabs in Prussia and Livonia, ${ }^{113}$ as well as effigies of Hospitaller officials on Rhodes, ${ }^{114}$ emphasised martial qualities over religious status and celibacy. ${ }^{115}$

The military orders also adopted recognisable portable symbols of authority. In regions where they minted their own coins, degrees of standardisation and long-term emblematic continuity are visible. Coins were produced by the Teutonic Order in Prussia and Livonia, and by the Hospitallers on Rhodes and later Malta (Fig 9). Aside from their economic function, the changing designs of these coins reflect the variable ideological emphasis of these two major orders. ${ }^{116}$ In the case of the Teutonic Order in Prussia, a range of designs is evident on its bracteates interpreted as symbolising its crusading ideology alongside expressions of lordship. ${ }^{117}$ By the reign of Winrich von Kniprode (1351-1382), the designs on larger coins emphasised the Order's cruciform emblem and the eagle of the Grand Master. The gold coins of Heinrich von Plauen (1410-1413), included a design of the Virgin Mary aimed at underlining the divine mandate of the Order's rule, contested in the war with Poland. ${ }^{118}$ This design was also used by Albrecht von Hohenzollern (1511-1525), but in the groats produced during his reign the Order's shield became replaced by the eagle of Brandenburg. ${ }^{119}$ The Order's political supremacy in Prussia was underlined by its monopoly 
over minting, with few examples of forgeries. In Livonia, when the Teutonic Order's branch minted coins in the late-14th century its corporate identity was expressed with the use of the cross and shield. However, the authority of the provincial Master was emphasised initially with an inscription and from 1471 with the addition of personal coats of arms. Ferdings struck in Reval during Wolter von Plettenburg's reign (1494-1535) also incorporated the familiar motif of the crowned Virgin and Child. ${ }^{120}$

The Hospitallers began minting coins in 1309 having acquired Rhodes, with the design adopted from its earlier seals and one that would continue to be used for a further two centuries - the Grand Master kneeling before a patriarchal cross - a visible connection with Jerusalem. ${ }^{121}$ Heraldic devices began to be used on the Order's coins during the reign of Roger de Pins (1355-65), and from c 1332 through to c 1377 the design of the billion denier imitated the Genoese denier, clearly expressing the alliance with the maritime republic which had contributed to securing Rhodes. ${ }^{122}$ When the Hospitallers settled Malta in 1530, they continued to produce coins expressing their sovereign rule emblematised by the arms of the Grand Master quartered with those of the Order and the Paschal Lamb / figural representations of St John. The figure of the Grand Master receiving the banner from St John was also used. However, the supra-national identity of the order also became regionally fragmented. Comparative analysis of Hospitaller seals used in the Latin East, France and England indicates a shift in the latter's sigillography from visual connections to the central administration of the order, to the head of St John, regularly adopted from the second decade of the 13th century. In contrast to Western depictions of the saint, this was more reminiscent of Byzantine icons, most likely a direct import from the East reflecting the mobility of the Order's officials. English Hospitallers therefore chose to distance themselves from the French Priory of St Gilles and the Latin East, with the saint promoted as the principal authority behind order. ${ }^{123}$ Coins and seals were therefore highly mobile insignia promoting both standardised and contested projections of the orders.

\section{THE CULTURAL LANDSCAPES OF THE MILITARY ORDERS}

The lens of landscape, in its broadest sense, is increasingly employed for investigating cultural change in the Middle Ages, a key component of the multi-scalar longue durée perspective. In the context of the military orders, the fundamental relationship between houses and their estates has already been outlined. In both frontiers and heartlands, the construction of a set of buildings by the military orders was invariably tied to the management - and protection - of a landscape, its people and resources. The management of estates in the West became an essential feature of the military orders from the mid-12th century, as a source of permanent revenue. ${ }^{124}$ The Templars established an organisational precedent which all other military orders emulated; the general administrative unit was the commandery, with other territorial subdivisions emerging with the increasing complexity of individual orders' administrations, such as the Teutonic Order's range of Ämter (districts). The term commandery referred to both the territory, which functioned in the same way as other ecclesiastical estates, and to the physical buildings from which it was administered. As indicated above, the latter have been the traditional starting point for any archaeological investigation, and their associated landscapes should not be considered as ephemeral additions or restricted to the interests of environmental archaeologists. They are diagnostic components of the archaeology of the military orders and to ignore them, to fall back on site plans and architecture as the sole research focus, is to fail to understand the multiple roles of the houses owned by various orders. The 
development of the estates held by orders involved the mobilisation of a workforce and tenants, with investment in settlement and infrastructure. The nuances of territorial organisation varied between the orders and changed over time, although all maintained a hierarchical structure dominated by regional houses or convents. In Europe, commanderies would send their surplus - money, goods or donations - to their provincial headquarters. These in turn would be sent on to the crusading frontiers. Frontier commanderies functioned in the same way. Here, resource exploitation was aimed at sustaining the orders' houses and producing a surplus for export, such as sugar from the Levant or grain and timber from the eastern Baltic. These territories also defined the orders as landlords, as institutions with political agency and social responsibilities.

Curiously this fundamental aspect of the military orders has attracted the least attention from archaeologists. Resource exploitation can be measured through a multi-proxy approach to the landscape, synthesising a diverse range of palaeoenvironmental data recovered from archaeological sites and depositional basins. Underpinning this is an essential reconstruction of related settlement patterns, communication and provisioning networks. Dariusz Poliński's study of changing settlement in the Kulmerland (modern central-north Poland) following its incorporation into the Teutonic Order's Prussian domain is, to date, exceptional, albeit focusing on settlement types, with little detailed artefactual analysis or environmental data. ${ }^{125}$ The Ecology of Crusading project sought to address the impact of the Teutonic Order on the landscape in the eastern Baltic with more detailed multi-proxy analyses, exchanging comprehensive studies of every settlement type for interregional comparisons of select commanderies. ${ }^{126}$ The results demonstrated regional differences in the character of resource exploitation linked, in part, to relationships with colonising and indigenous communities. Gerrard's detailed research at Ambel has developed a robust model for settlement which can now be connected with observed changes in the broader territory of the Templars and Hospitallers; ${ }^{127}$ further south, Castillo Armenteros' sustained study of the Upper Guadalquivir (southern Spain) has contextualised the Order of Calatrava's role in the management of this frontier. ${ }^{128}$ Boas and Khamesi's work at Montfort is also planned to extend to the associated estates of the Teutonic Order in the Galilee, although the historical groundwork mapping the estates of the military orders around Acre has already been done. ${ }^{129}$ The cultural landscapes created by the military orders in striving to maximise their resource outputs can ultimately be connected with the theme of investment. The mills, sugar refineries and production centres on the orders' estates required capital, energy and security, and whilst historical sources are an essential component of reconstructing the diachronic network of these installations, their material traces provide a useful index of relative investment which can be integrated with studies of other settlement types, including the administrative centres of the military orders. ${ }^{130}$ Moving beyond these discrete regional studies, a holistic understanding of the military orders must recognise the supranational networks which connected the varied and shifting mosaic of territories in the heartlands and frontiers of Latin Europe.

\section{CONCLUSIONS}

The military orders may seem, on the face of it, like an obscure and highly specialised niche of study for archaeologists. In fact, they are the opposite. Historians have moved away from viewing them as 'an eccentric manifestation of spiritual enthusiasm' to situating them within the mainstream of medieval society. ${ }^{131}$ Unlike all other expressions of monasticism, their economic strategies were geared towards supporting crusading and the related 
provision of welfare for pilgrims, ${ }^{132}$ which included the maintenance of estates and infrastructure in both the frontiers and heartlands of Europe. This raison d'être was at the heart of the orders' very existence. The ultimate failure of the Templars and Lazarites contrasted with the successful re-branding of holy war in north-eastern Europe by the Teutonic Order. Here the Crusades resulted in the creation of theocratic polities principally governed by the Order. In both Prussia and Livonia, the Order dominated the hybrid cultures created from an uneven merger of native and colonising societies into the 16th century, whilst knights and their retinues from all corners of Latin Europe undertook the expensive and at times fatal crusade to fight alongside the Order against the Lithuanians throughout the 14th century. ${ }^{133}$ The Hospitallers also reframed their purpose in the 14th century as the containment of Turkish expansion in the eastern Mediterranean, and were sovereigns within their Dodecanese island domains - the frontier with the expanding sultanate. They became reliant on the economic exploitation of their domains and continued resourcing from their European estates. The Iberian military orders, as frontier authorities, gave the territorial division between Christian and Muslim polities an enduring crusading character, yet their responses to conquered Muslim communities varied considerably. ${ }^{134}$ In the context of Portuguese expansionism framed as crusading, ${ }^{135}$ the reconstituted Portuguese Templars, the Order of Christ, was given responsibility to oversee Portuguese conquests by Pope Calixtus III in 1456, and actively encouraged to participate in crusades into Africa. ${ }^{136}$

Historians have moved beyond the overarching narratives of the orders to tackle a range of complex questions relating to their social roles. This contrasts with archaeological knowledge of a limited number of sites, dominated by descriptive recording, particularly of architectural features and layouts. Relatively little attention has been paid to other types of sites, almost no work has considered entire commanderies, integrating the houses of the orders with their cultural landscapes. Even fewer attempts have been made to systematically compare the frontiers of Christendom with its heartlands. Future archaeological research would benefit from a clear research agenda, bridging these geographic distances and adopting a multi-scalar approach to the military orders. Regional studies have demonstrated how the military orders shaped settlement patterns, reorganised the landscape and protractedly intensified the exploitation of local resources. ${ }^{137}$ These studies have also demonstrated a range of variability and adaptations, characterising the military orders as hierarchical, corporate institutions that were nonetheless extremely versatile. This, in turn, reflects both the collective and individual elements observed in the leadership structures of the orders. ${ }^{138}$ This paper has demonstrated how degrees of standardisation and heterogeneity across the domains of the military orders provide a valuable material commentary on the supranational integrity of these institutions.

Archaeologists are well placed to contribute new understanding of the controversial institutions that played a major role in the formation of European identity, and which represent important intersections between academic knowledge and public understanding of the crusading movement. ${ }^{139}$ The benefit of substantial historical scholarship on the Crusades and the military orders is that questions have been raised which are difficult to answer, or fully answer, with written sources, but which can potentially be addressed with archaeology. Archaeologists, in turn, will raise new questions with which historians can engage. Archaeological data is multi-scalar and can be situated within long-term diachronic trends, providing the military orders with a context. Umberto Eco famously wrote, several years after The Holy Blood and the Holy Grail had become an international bestseller, ${ }^{140}$ that: 
You can tell [a lunatic] ... by the fact that sooner or later he brings up the Templars ... There are lunatics who don't bring up the Templars, but those who do are the most insidious. ${ }^{141}$

Here I have argued that archaeologists need to bring up the Templars - and the rest - a lot more often.

\section{ACKNOWLEDGEMENTS}

This paper has benefitted from ongoing discussions with colleagues, and I would particularly like to thank Roberta Gilchrist, Grenville Astill, Guillermo García-Contreras Ruiz, Adrian Boas, Balázs Major, Chris Gerrard and Jonathan Phillips.

\section{BIBLIOGRAPHY}

Apals, J 1996, Vēstures avotu ziṇas par Āraišu mūra pili', Arheoloǵija un etnogrāfija 18, 2737.

Aronstein, S and Torry, R 2009, 'Chivalric conspiracies: Templar romance and the redemption of history in National Treasure and The Da Vinci Code', in N Haydock and E L Risden (eds), Hollywood in the Holy Land: Essays on Film Depictions of the Crusades and Christian-Muslim Clashes, Jefferson, NC: McFarland, 225-245.

Atzbach R 2009, 'Wasserversorgung und Entsorgung des Deutschordenshauses Marburg: Befunde vom 13. bis zum 18. Jh', Mitteilungen der Deutschen Gesellschaft für Archäologie des Mittelalters und der Neuzeit 21, 173-180.

Baigent, M Leigh R and Lincoln H 1982, The Holy Blood and the Holy Grail, London: Cape. Barber, M 1994a, The Military Orders: Fighting for the Faith and Caring for the Sick, Farnham: Ashgate.

Barber, M 1994b, The New Knighthood: A History of the Order of the Temple, Cambridge: Cambridge University Press.

Baudin, A, Brunel, G and Dohrmann, N (eds) 2012, L'économie templière en Occident: Patrimoines, commerce, finances - Actes du colloque international, Langres: Éditions Dominique Guéniot.

Boas, A 2017, Crusader Archaeology: The Material Culture of the Latin East, 2nd edn, London: Routledge (first edition 1999).

Boas, A 2006, Archaeology of the Military Orders: A Survey of the Urban Centres, Rural Settlement and Castles of the Military Orders in the Latin East (c. 1120-1291), London: Routledge.

Boas, A (ed) 2016, The Crusader World, London: Routledge

Boas, A and Khamisy, R G (eds) 2017, Montfort: History, Early Research and Recent Studies of the Principal Fortress of the Teutonic Order, Leiden: Brill.

Bom, M M 2012, Women in the Military Orders of the Crusades, New York: Palgrave Macmillan.

Borchardt, K 2001, 'The Templars in Central Europe', in Hunyadi and Laszlovszky, 233-244.

Borchardt, K 2016, 'The military-religious orders in the crusader West', in Boas, 111-127.

Brenot, J, Caillot, I and Messager, E et al 2013, 'Le site du Carreau du Temple (Paris) entre "marais" et "marécages": indices géoarchéologiques et paléo-environnementaux', Rev Archéol Centre France 52, 345-365.

Brus, B 2004, 'Sporen van de Tempelorde. Een poging tot reconstructie van de aanwezigheid van Tempeliers in ons land', Westerheem 53:4, 157-164. 
Bueno Pimenta, F 2004, 'Carisma y espiritualidad de la Orden de San Juan de Jerusalén', Archivo Hispalense 86/87:261-266, 339-377.

Burgtorf, J 2008, The Central Convent of Hospitallers and Templars, Leiden: Brill.

Burgtorf, J and Nicholson, $\mathrm{H}$ (eds) 2006, International Mobility in the Military Orders: Travelling on Christ's Business. Twelfth to Fifteenth Centuries, Cardiff: University of Wales Press.

Carlsson, C 2006, 'The religious orders of knighthood in medieval Scandinavia: historical and archaeological approaches', Crusades 5, 131-142.

Carraz, D 2008, 'Archéologie des commanderies de l'Hôpital et du Temple en France (19772007)', Cahiers de recherches médiévales (XIIle-XVe siècles) 15, 175-202.

Carraz, D (ed) 2013a, Les ordres militaires dans la ville médiévale (1100-1350), ClermontFerrand: Presses Universitaires Blaise-Pascal.

Carraz, D 2013b, 'Templars and Hospitallers in the Cities of the West and the Latin East (Twelfth to Thirteenth Centuries)', Crusades 12, 103-120.

Carraz, D 2014, 'Templar and Hospitaller establishments in southern France: The state of research and new perspectives', in Piana and Carlsson, 107-131.

Castillo Armenteros, J C and Castillo Armenteros, J L 2003, 'La organización militar de la Ordende Calatrava en el Alto Guadalquivira través de las investigaciones arqueológicas', Arqueología y Territorio Medieval 10:2, 181-231.

Chen-Wing, R 2012, 'The Knights of St John of Jerusalem as prototypical NGO', Tiresias 1, 5155.

Ciglis, J 2002, 'Rīgas pils 16. gadsimta telpu izvietojuma rekonstrukcijas mēǵinājums', [An attempt to reconstruct the $16^{\text {th }}$ century palace at Riga castle] Latvijas Viduslaiku Pilis 3, 119-163.

Crawford, P F 2014, 'Gregory VII and the idea of a military-religious order', in S B Edgington and H J Nicholson (eds), Deeds Done Beyond the Sea: Essays on William of Tyre, Cyprus and the Military Orders Presented to Peter Edbury, Farnham: Ashgate, 171180.

Dutra, F A 1970, 'Membership in the Order of Christ in the seventeenth century: Its rights, privileges, and obligations', Americas 27:1, 3-25.

Dygo, M 1989, 'The political role of the cult of the Virgin Mary in Teutonic Prussia in the fourteenth and fifteenth centuries', J Medieval Hist 15:1, 63-81.

Eco, U 1989, Foucault's Pendulum, London: Guild.

Edbury, P (ed) 2012, The Military Orders 5: Politics and Power, Aldershot: Ashgate.

Feutcher, J 2012, 'Europe penetrated by Islam. The orientalization of the Order of the Templars', in K Hock and G Mackenthun (eds), Entangled Knowledge: Scientific Discourses and Cultural Difference, Münster: Waxmann, 77-92.

Fonseca, L A da 2016, 'The idea of crusade in medieval Portugal, political aims and ideological framing', in T K Nielsen and I Fonnesberg-Schmidt (eds), Crusading on the Edge: Ideas and Practice of Crusading in Iberia and the Baltic Region, 1100-1500, Turnhout: Brepols, 177-197.

Forey, A 1984, 'The military orders and the Spanish Reconquest in the twelfth and thirteenth centuries', Traditio 40, 197-234.

Forey, A 2002, 'The military orders and the conversion of Muslims in the twelfth and thirteenth centuries', J Medieval Hist 28, 1-22.

Gancewski, J 2001, Rola zamków krzyzackich w ziemi chelminskiej od polowy XIV wieku do 1454 roku, [The role of the Teutonic Order's castles in the Kulmerland from the mid- 
14th century until 1454] Olsztyn: Ośrodek Badań naukowych im, Wojciecha Kętrzyńskiego.

García-Guijarro Ramos, L 2008, 'Historiography and history: medieval studies on the military orders in Spain since 1975', in V Mallia-Milanes (ed), The Military Orders 3: History and Heritage, Farnham: Ashgate, 23-43.

Gerrard, C 1999, 'Opposing identity: Muslims, Christians and the military orders in rural Aragon', Medieval Archaeol 43, 143-160.

Gilchrist, R 1992, 'Knight clubs: an archaeology of the military orders', in G de Boe and $\mathrm{F}$ Verhaeghe (eds), Medieval Europe: Religion and Belief, York: Medieval Europe, 6570.

Gilchrist, R 1995, Contemplation and Action: The Other Monasticism, London: Leicester University Press.

Gilchrist, R 2009, 'Rethinking later medieval masculinity: the male body in death', in D Sayer and H Williams (eds), Mortuary Practices and Social Identities in the Middle Ages, Exeter: Exeter University Press, 236-52.

Gilmour-Bryson, A 2008, 'A look through the keyhole: Templars in Italy from the trial testimony', in Zajac, 123-130.

Gładysz, M 2012, The Forgotten Crusaders: Poland and the Crusader Movement in the Twelfth and Thirteenth Centuries, Leiden: Brill.

Gómez de Terreros Guardiola, M d V 2010, La arquitectura de las órdenes militares en Andalucía: conservación y restauración, Huelva: Universidad de Huelva.

Griffith-Jones, R, and Park, D (eds) 2010, The Temple Church in London: History, Architecture, Art, Woodbridge: Boydell.

Grupa, M and Kozłowski, T (eds) 2009, Katedra w Kwidzynie - tajemnica krypt, [The cathedral in Kwidzyn - the secret of the crypt] Kwidzyn: Kwidzyńskie Centrum Kultury.

Haljak, G 2010, Livonian Coins XIII -XVIII Century, Part I: Feudal States, Tallinn: Gunnar Haljak.

Henry, M 2006, Les ordres militaires en Lorraine, Metz: Serpenoise.

Herrmann, C 2007, Mittelalterliche Architektur in Preussenland: Untersuchungen zur Frage der Kunstlandschaft und -geographie, Petersberg: Michael Imhof Verlag.

Hunyadi, Z and Laszlovszky, J (eds) 2001, The Crusades and the Military Orders: Expanding the Frontiers of Medieval Latin Christianity, Budapest: Central European University.

Hyacinthe, R 2003, L'ordre de Saint-Lazare de Jérusalem au Moyen Âge, Millau Bez-etEsparon: Conservatoire Larzac Templier et Hospitalier.

Ioniţă, A, Căpăţână, D and Boroffka, N et al 2004, Feldioara/Marienburg - Contribuţii arheologice la istoria Jării Bârsei/Archäologische Beiträge zur Geschichte des Burzenlandes, [Feldioara / Marienburg - Archaeological Contributions to the History of the Burzenland] Bucharest: Editura Academiei Romane.

Izquierdo, R and Ruiz Gómez, F (eds) 2000, Las órdenes militares en la Península Ibérica, Cuenca: Ediciones de la Universidad de Castilla-La Mancha.

Jankrift, K P 2006, 'International mobility in the Order of St Lazarus (twelfth to early fourteenth centuries)', in Burgtorf and Nicholson, 59-64.

Jansen, V 2010, 'Light and pure: The Templars' new choir', in Griffith-Jones and Park, 45-66.

Jurkowlaniec, T 2010, 'Z Prus do wieczności...o nagrobkach' [From Prussia to eternity...on tombstones], in B Pospieszna (ed), Fundacje artystyczne na terenie Państwa Krzyżackiego w Prusach, Pelplin: Wydawnictwo Bernardinum, 213-222. 
Kasdagli, A-M 2008, 'Funerary monuments of Hospitaller Rhodes: an overview', in J UptonWard (ed) 2008, The Military Orders 4: On Land and by Sea, Farnham: Ashgate, 175188.

Kasdagli, A-M 2013, 'Hospitaller small change: an archaeological perspective', in E Buttigieg and S Phillips (eds), Islands and the Military Orders, c 1291-c 1798, Farnham: Ashgate, 203-213.

Khamisy, R 2013, 'The Templar estates in the territory of Acre', Ordines Militares 18, 267285.

Knobler, A 2006, 'Holy wars, empires, and the portability of the past: The modern uses of medieval crusades', Comparative Stud Society Hist 48:2, 293-325.

Kola, A 2002, 'Wiejskie osadnictow obronne na terenie ziemi chełmińskiej w późnym Średniowieczu', [Fortified rural settlement in the Kulmerland in the Late Middle Ages] in B Wawrzykowska (ed), Archeologia Toruńska. Historia i teraźniejszość, Toruń: Muzeum Okręgowe w Toruniu, 151-164.

Lacerda, M and Parada, A C (eds) 2013, Encontro Internacional Castelos das Ordens Militares, Tomar, 2012: Castelos das Ordens Militares (2 volumes), Lisbon: Direção Geral do Património Cultural.

Laszlovszky, J 2001, 'Crusades and military orders: state of research', in Hunyadi and Laszlovszky, 3-20.

Laszlovszky, J and Soós, Z 2001, 'Historical monuments of the Teutonic Order in Transylvania', in Hunyadi and Laszlovszky, 319-336.

Lord, E 2002, The Knights Templar in Britain, Edinburgh: Pearson Education.

Luttrell, A 2003, The Town of Rhodes: 1306-1356, Rhodes: City of Rhodes Office for the Medieval Town.

Luttrell, A 2014, 'Introduction: history and archaeology', in Piana and Carlsson, 1-4.

Luttrell, A and Nicholson, $\mathrm{H} J$ (eds) 2006, Hospitaller Women in the Middle Ages, Aldershot: Ashgate.

Major, B 2013, 'Bathing in the Latin East: A recently discovered 13th century bathhouse in alMarqab citadel (Syria)', Hungarian Archaeol E-J, Winter Edition, 1-7.

Major, B 2015, 'A special type of "urban site" in the 13th century Levant? The case of Margat (Qal'at al-Marqab)', in A Riera, J Guitart and S Giner (eds), Ciutats mediterrànies, civilització i desenvolupament, Barcelona: Institut d’Estudis Catalans, 195-198.

Major, B and El-Ajji, E 2011, 'Al-Marqab Research Project of the Syro-Hungarian Archaeological Mission (A brief report on the activities of 2009)', Chronique Archéol Syrie 5, 263-283.

Mallia-Milanes, V (ed) 2008, The Military Orders 3: History and Heritage, Farnham: Ashgate. Marceli, K 2011, 'Bitwa pod Grunwaldem - szesc wieków w narodowej pamięci' [The battle of Grunwald - six centuries of national memory], Przeglqd Zachodni 1:338, 105-130.

Marcombe, D 2003, Leper Knights: The Order of St Lazarus of Jerusalem in England, 11501544, Woodbridge: Boydell.

Marcombe, D 2006, 'The Order of St Lazarus in England', in Burgtorf and Nicholson, 34-47.

Mayes, P 2002, Excavations at a Templar Preceptory, South Witham, Lincolnshire, 1965-67, Leeds: Maney.

Mclntosh, C 2011, The Rose Cross and the Age of Reason: Eighteenth-century Rosicrucianism in Central Europe and its Relationship to the Enlightenment, Albany: State University of New York Press. 
Metcalf, D M 1995, Coinage of the Crusades and the Latin East in the Ashmolean Museum Oxford, London: Royal Numismatic Society and Society for the Study of Crusades and the Latin East.

Miehle, D 1998, Monety Zakonu Krzyżackiego, [The coins of the Teutonic Order] Warszawa: Muzeum Narodowe w Warszawie.

Mitchell, P D, Huntley, J and Stern, E 2008, 'Bioarchaeological analysis of the 13th century latrines of the crusader hospital of St John at Acre, Israel', in Zajac, 213-23.

Mol, E 2012, Hidden Complexities of the Frankish Castle: Social Aspects of Space in the Configurational Architecture of Frankish Castles in the Holy Land, 1099-1291, Leiden: Leiden University Press.

Morton, N 2009, The Teutonic Knights in the Holy Land: 1190-1291, Woodbridge: Boydell. Morton, N 2013, The Medieval Military Orders: 1120-1314, Harlow: Pearson.

Nicholson, $\mathrm{H}$ (ed) 1998, The Military Orders 2: Welfare and Warfare, Farnham: Ashgate.

Nicholson, H 2001a, The Knights Templar: A New History, Stroud: Sutton.

Nicholson, H 2001b, The Knights Hospitaller, Woodbridge: Boydell and Brewer.

Nicholson, H 2001c, 'The military orders and their relations with women', in Hunyadi and Laszlovszky, 407-414.

Nicholson, H 2005, 'Saints venerated in the military orders', in R Czaja and J Sarnowsky (eds), Selbstbild und Selbstverständnis der geistlichen Ritterorden: Die Rezeption der Idee und die Wirklichkeit, Toruń: Wydawnictwo Uniwersytetu Mikołaja Kopernika, 91-113.

Nicholson, H 2006, 'International mobility versus the needs of the realm: the Templars and Hospitallers in the British Isles in the thirteenth and fourteenth centuries', in Nicholson and Burgtorf, 87-101.

Nicholson, $\mathrm{H}$ 2010, 'At the heart of medieval London. The New Temple in the Middle Ages', in Griffith-Jones and Park, 1-18.

O'Malley, G 2013, 'Some aspects of the use and exploitation of mills by the Order of St John in Rhodes and Cyprus', in E Buttigieg and S Phillips (eds), Islands and the Military Orders, c 1291-c 1798, Farnham: Ashgate, 225-238.

Ose, I 2002, 'Ordenpilis Lavijā' [The Teutonic Order's Latvian castles], Latvijas Viduslaiku Pilis 3, 9-48.

Paravicini, W 1989,[Die Preussenreisen des europäischen Adels (2 volumes), [The Prussian 'Reisen' (campaigns) of the European nobility ]Sigmaringen: Thorbecke.

Paszkiewicz, B 2009, Brakteaty - pieniqdz średniowiecznych Prus, [Bracteates - the money of medieval Prussia] Wrocław: Wydawnictow Uniwersytetu Wrocławskiego.

Pechuro, A, Kloner A and Cohen, M 2011, 'Sculptural fragments of the furniture from the crusader church at Beth Guvrin', Levant 43:1, 51-77.

Pereira, P 2003, De Áurea Aetatis. A iconografia manuelina da fachada ocidental do Coro do convento de Cristo em Tomar, Lisbon: IPPAR.

Piana, M and Carlsson, C (eds) 2014, Archaeology and Architecture of the Military Orders: New Studies, Farnham: Ashgate.

Pluskowski, A G 2010, 'The zooarchaeology of medieval 'Christendom': ideology, the treatment of animals and the making of medieval Europe', World Archaeol 42:2, 201214.

Pluskowski, A G 2013, The Archaeology of the Prussian Crusade: Holy War and Colonisation, London: Routledge.

Pluskowski, A G 2017, Terra Sacra: Environment, Colonisation, and the Crusader States in Medieval Livonia and Prussia, Turnhout: Brepols. 
Pluskowski, A G and Valk, H 2016, 'Conquest and Europeanisation: The Archaeology of the Crusades in Livonia, Prussia and Lithuania', in Boas, 568-592.

Poliński, D 2003, Późnośredniowieczne osadnictwo wiejskie w ziemi chełmińskiej, [Late medieval rural settlement in the Kulmerland] Toruń: Wydawnictwo Uniwersytetu Mikolaja Kopernika.

Pospieszna, B (ed) 2010, Fundacje artystyczne na terenie Państwa Krzyżackiego w Prusach, two volumes, Malbork: Muzeum Zamkowe w Malborku.

Pospieszna, B and Pospieszny, K 2014, 'Kloster-Residenzen oder Wehrbauten der „MarienDiener" in Preußen - zwei Bilder der Deutschordensburgen einst und heute', [Monastic residences or defensive buildings of the "Marien-Diener" in Prussia - two pictures of the Teutonic Order's castles once and today] Castrum Bene 12, 221-232.

Pospieszny, K 2002, 'Über den Gebrauch der Gebrannten erde zur Bildnerei. Warsztaty ceglarski i plastyka architektoniczna zamku w Malborku w XIII i XIV w', [The brick workshop and architectural design of Malbork Castle in the 13th and 14th centuries] in M Arszyński and M Mierzwiński (eds), Cegła w architekturze środkowo-wschodniej Europy, Malbork: Muzeum Zamkowe w Malborku, 163-179.

Riley-Smith, J 2009, Templars and Hospitallers as Professed Religious in the Holy Land, Paris: University of Notre Dame Press.

Rodríguez-Picavea, E 2008, Los monjes guerreros en los reinos hispánicos. Las órdenes militares en la Península Ibérica durante la edad media, Madrid: La Esfera de los Libros.

Ruiz Gómez, F 2002, 'Los hijos de Marta, las órdenes militares y las tierras de la Mancha en el siglo XII', Hispania: Revista española de historia 62i:210, 9-40.

Sander, R P 1995, 'The contribution of Post-World War II schools in Poland in forging a negative image of the Germans', East European Quarterly 29:2, 169-187.

Salvadó, S 2011, 'Templar liturgy and devotion in the Crown of Aragon', in H Nicholson (ed), On the Margins of Crusading: The Military Orders, the Papacy and the Christian World, Farnham: Ashgate, 31-44.

Sarnowsky, J 2011, 'Military orders and power - Teutonic Knights, Hospitallers, and their 'Order State", in J Sarnowsky (ed), On the Military Orders in Medieval Europe, Farnham: Ashgate, 1-11.

Schenk, J G 2010, 'Nomadic violence in the first Latin kingdom of Jerusalem and the military orders', Reading Medieval Stud 36, 39-55.

Schenk, J G 2012, 'The cult of the cross in the Order of the Temple', in I C Ferreira Fernandes (ed), As Ordens Militares. Freires, Guerreiros, Cavaleiros, Palmela, GEsOS / Município de Palmela, 207-219.

Selwood, D 2002, Knights of the Cloister: Templars and Hospitallers in Central-Southern Occitania, c 1100-c 1300, Woodbridge: Boydell.

Skalski, P 1996, 'Duchowość zakonów rycerskich w średniowieczu', [The spirituality of the medieval knightly orders] Saeculum Christianum 3:1, 151-165.

Sloane, B and Malcolm, G 2004, Excavations at the Priory of the Order of the Hospital of St John of Jerusalem, Clerkenwell, London, London: Museum of London.

Stathakopoulos, G 2006, 'Discovering a military order of the crusades: The hospital of St Sampson of Constantinople', Viator 37, 255-273.

Steinbrecht, C 1920, Die Ordensburgen der Hochmeisterzeit in Preussen, Berlin: Springer.

Torbus, T 2014, 'The architecture of the castles in the Prussian state of the Teutonic Order', in Piana and Carlsson, 219-249. 
Tyerman, C, 2011, The Debate on the Crusades, 1099-2010, Manchester: Manchester University Press.

Tyerman, C 2013, 'Review of Templar Families: Landowning Families and the Order of the Temple in France, c.1120-1307, by Jochen Schenk', Church Hist 82:4, 957-959.

Tyerman, C 2015, 'Violence and holy war in Western Christendom', in R N Swanson (ed), The Routledge History of Medieval Christianity 1050-1500, London: Routledge, 185-196.

Urban, W 1993, 'Medieval Livonian numismatics', J Baltic Stud 24:1, 37-52.

Upton-Ward, J (ed) 2008, The Military Orders 4: On Land and by Sea, Farnham: Ashgate.

Vairo, G R 2014, 'Originality and adaptation: the architecture of the Teutonic Order in Italy', in Piana and Carlsson, 193-218.

Valk, H, Rannamäe, E and Brown, A D et al 2013, 'Thirteenth century cultural deposits at the castle of the Teutonic Order in Karksi', Archaeol Fieldwork Estonia 2012, 73-92.

Vann, T M 2006, 'The exchange of information and money between the Hospitallers of Rhodes and their European priories in the fourteenth and fifteenth centuries', in Burgtorf and Nicholson, 34-47.

Whatley, L J 2012, 'Visual self-fashioning and the seals of the Knights Hospitaller in England', in N Paul and S Yeager (eds), Remembering the Crusades: Myth, Image and Identity, Baltimore: The John Hopkins University Press, 252-269.

Wiewióra, M (ed) 2012, Zamek w Grudziq̨dzu w świetle badań archeologiczno architektonicznych. Studia i materiały, Grudziądz: Muzeum w Grudziądzu.

Wilson, C 2010, 'Gothic architecture transplanted. The nave of the Temple Church in London', in Griffith-Jones and Park, 19-44.

Wright, L P 1969, 'The military orders in sixteenth and seventeenth century Spanish society. The institutional embodiment of a historical tradition', Past and Present 43, 34-70.

Zajac, W (ed) 2008, The Military Orders 3: Their History and Heritage, Aldershot: Ashgate. Zeebroek, I, Jansseune, G and Tys, D et al 2006, 'Het Groot-Tempelhof te Slijpe, de oude Commanderie de Flandres van de orde van de tempelridders (gem. Middelkerke, prov. West-Vlaanderen). Geïntegreerde analyse van het landschap, archiefbronnen en opgravingsresultaten 1971-2003', [The Groot-Tempelhof in Slijpe, the old Templar commandery of Flanders. Integrated analysis of the landscape, archives and results of the excavations in 1971-2003] Relicta 1, 155-182.

ABBREVIATIONS

\section{Résumé}

L'archéologie des ordres militaires : la culture matérielle de la Guerre Sainte par Aleks Pluskowski

Ce papier examine l'état actuel de la recherche dans le domaine de l'archéologie des ordres militaires. Il met en contraste les avancées effectuées d'une part par les historiens et, d'autre part, par les archéologues, ces derniers continuant à se focaliser sur la particularité de sites individuels, en mettant l'accent sur les analyses architecturales. En adoptant une approche supranationale, les historiens ont contribué à offrir de nouvelles perspectives. Ce papier fait valoir que les archéologues peuvent développer ceci en adoptant une approche comparative, plus axée sur les problèmes. En puisant dans des exemples de territoires 
frontaliers et centraux, les approches archéologiques sont divisées selon l'investissement matériel, l'identité matérielle et les paysages culturels, afin de placer les sites d'ordres militaires dans un contexte multiscalaire, à long terme. Ceci contribue à une connaissance socioéconomique plus large des ordres, qui ont contribué significativement à l'urbanisation, au développement rural et au négoce, et ont investi dans des expressions matérielles de leur autorité et de leur idéologie. Le papier conclut que des approches plus holistiques, interrégionales feront avancer l'étude archéologique des ordres militaires.

\section{Zusammenfassung}

Die Archäologie der Ritterorden: Die materielle Kultur des Heiligen Kriegs von Aleks Pluskowski

Dieser Artikel begutachtet den aktuellen Forschungsstand in der Archäologie der Ritterorden. Er stellt die Ansätze von Historikern und Archäologen gegeneinander, wobei die letzteren sich weiterhin auf die Besonderheiten einzelner Fundstätten mit Betonung auf architektonische Analyse konzentrieren. Historiker haben durch die Verwendung eines länderübergreifenden Ansatzes neue Einsichten beigesteuert. Dieser Artikel argumentiert, dass Archäologen darauf aufbauen können, indem sie ebenfalls einen eher problemorientierten, komparativen Ansatz übernehmen. Am Beispiel von Grenz- und Kerngebieten werden archäologische Ansätze in materielle Investitionen, materielle Identität und Kulturlandschaften weiter unterteilt, um die Stätten der Ritterorden in einen langfristigen, multiskalaren Kontext zu setzen. Das trägt zu einem breiteren gesellschaftlichen und wirtschaftlichen Verständnis der Orden bei, die einen bedeutsamen Beitrag zur Urbanisierung, zur ländlichen Entwicklung und zum Handel geleistet und in den materiellen Ausdruck ihrer Autorität und Ideologie investiert haben. Der Artikel kommt zu dem Schluss, dass holistischere, interregionale Ansätze die archäologische Untersuchung der Ritterorden vorwärts bringen können.

\section{Archeologia degli ordini militari: la cultura materiale della Guerra santa di Aleks Pluskowski}

Questo studio esamina lo stato attuale della ricerca sull'archeologia degli ordini militari. Si mettono a confronto i progressi fatti dagli storici con quelli fatti dagli archeologi, laddove questi ultimi continuano a concentrare l'attenzione sul particolarismo di siti individuali mettendone in evidenza le analisi architettoniche. Gli storici hanno contribuito ad accrescere le conoscenze adottando un approccio supernazionale. Qui si sostiene che gli archeologi possono farne tesoro con un approccio comparativo diretto al problema. Basandosi su esempi di territori di frontiera e di territori centrali di un paese, gli approcci archeologici sono suddivisi in investimento materiale, identità materiale e paesaggi culturali per porre gli ordini militari in un contesto a lungo termine multiscalare. Questo contribuisce a ottenere una più ampia comprensione sociale ed economica degli ordini, i quali diedero un apporto significativo all'urbanizzazione, allo sviluppo rurale e al commercio e investirono nelle espressioni materiali della propria autorità e ideologia. Lo studio conclude che approcci più olistici, interregionali porteranno all'avanzamento dello studio archeologico degli ordini militari. 
The castle at Malbork (German 'Marienburg') in Poland. Photograph by Coptertech 2016.

FIG 2

Plans of the Teutonic Order's Konventsburgen in Prussia: (a) Brandenburg, (b) Rehden (1888, Steinbrecht), (c) Riga, basement and first floor plan reconstructions as rebuilt in the sixteenth century (plans after Ciglis 2002, 124, 127).

FIG 3

Ground plan of the procurator's castle at Neidenburg (Polish 'Nidzica') with chapel in lower left-hand corner (dated to c 1404; Steinbrecht 1920, fig. 128; reproduced in Herrmann 2007, 613).

FIG 4

Comparative plans of a few Templar churches and the Hospitaller church of St. John in Clerkenwell, London (by Jansen 2010, fig. 4)

FIG 5

Military order houses in their urban contexts: (a) Tortosa (Arabic 'Tartus'), Templars, after Boas 2006 (with permission), and (b) Fellin (Estonian 'Viljandi'),Teutonic Order, modified by author after Haak and Russow 2013, fig 2 (with permission).

FIG 6a

Stained glass with grisalle decoration recovered from Montfort castle (German 'Starkenburg'). Photograph by Adrian Boas, with permission.

FIG $6 \mathrm{~b}$

Glazed ceramic fragments from the Teutonic Order's compound in Acre, northern Israel Photograph by Adrian Boas, with permission.

FIG 7

The church at the Convent of Christ in Tomar, Portugal with the octagonal charola. Photograph by the author.

FIG 8

The western façade of the Manueline choir of the Convent of Christ in Tomar, Portugal. Photograph by the author.

FIG 9

Coins minted by the Teutonic Order in Prussia and by the Hospitallers in Rhodes: (a) Schilling of Winrych von Kniprode (1351-1382); (b) Groat of Albrecht von Hohenzollern (1513), Warsaw Numismatic Centre; (c) Ferding of Walter von Plettenberg including his arms quartered with the Order's cross (1515), Haljak 2010, 102, 87b; (d) 'Genose gate' anonymous billion denier, Rhodes (14th century), after Kasdagli 2013, 206, fig. 18.1.

${ }^{1}$ Department of Archaeology, University of Reading, Whiteknights, Reading RG6 6AB, UK. a.g.pluskowski@reading.ac.uk 
${ }^{2}$ Crawford 2014.

${ }^{3}$ Borchardt 2016.

${ }^{4}$ Tyerman 2015, 193.

${ }^{5}$ Riley-Smith 2009. Not in bib, is date incorrect or does 2008 need adding to bib?

${ }^{6}$ Knobler 2006, 232.

7 Feutcher 2012.

${ }^{8}$ Aronstein and Torry 2009, 225.

${ }^{9}$ Mclntosh 2011, 40.

${ }^{10}$ Chen-Wing 2012.

${ }^{11}$ Torbus 2014.

12 Sander 1995, 173-175.

13 Pospieszna and Pospiezny 2014.

14 Marceli 2011.

${ }^{15}$ Wright 1969.

${ }^{16}$ García-Guijarro Ramos 2008.

${ }^{17}$ Forey 1984; Izquierdo and Ruiz Gómez 2000.

${ }^{18}$ Rodríguez-Picavea 2008.

${ }^{19}$ Gómez de Terreros Guardiola 2010.

20 Morton 2013, 8.

21 Tyerman 2011, 206-207.

22 Eg Riley-Smith 2009, not in bib is date supposed to be 2009?; Sarnowsky 2011; Morton 2013; Borchardt 2016; Barber 1994b a or b?; Nicholson 2001a, 2001b; the series dedicated to the Teutonic Order, Quellen und Studien zur Geschichte des Deutschen Ordens has been published from 1966 until the present.

${ }^{23}$ Nicholson 1998

${ }^{24}$ Edbury 2012.

25 Baudin et al 2012.

${ }^{26}$ Nicholson and Burgtorf 2006; Upton-Ward 2008; Carraz $2013 a$.

27 Carraz 2013b.

${ }^{28}$ Eg Nicholson 2001c; Luttrell and Nicholson 2006; Bom 2012.

${ }^{29}$ Eg Skalski 1996, Bueno Pimenta 2004, Nicholson 2005.

${ }^{30}$ Riley-Smith 2009.

${ }^{31}$ Barber 1994a a or b?, Hunyadi and Laszlovszky 2001.

32 Salvadó 2011.

33 Borchardt 2001.

${ }^{34}$ Eg Selwood 2002; Ruiz Gómez 2002; Henry 2006; Schenk 2010.

${ }^{35}$ Eg Marcombe 2003.

36 Tyerman 2011, 219.

${ }^{37}$ Nicholson 2001a.

${ }^{38}$ Marcombe 2003, 142-154.

${ }^{39}$ Luttrell 2014, 1.

40 Sloane and Malcolm 2004.

${ }^{41}$ Griffith-Jones and Park 2010; Pospieszna 2010.

42 Luttrell 2014, 4.

${ }^{43}$ Boas 2006. 
${ }^{44}$ Boas 2017. (see comment regarding which edition used). The original edition was published in 1999.

45 Pluskowski 2013 not in bib (yes, 2012 was wrong - have changed); Pluskowski and Valk 2016.

46 Lacerda and Parada 2013.

${ }^{47}$ Castillo Armenteros and Castillo Armenteros 2003; see also Castillo Armenteros et al in Lacerda and Parada 2013.

48 Luttrell 2003, 78-134.

${ }^{49}$ Vann 2006 2006? Or add to bib?, 44.

50 Gładysz 2012, 118-120.

51 Laszlovszky and Soós 2001; loniţă et al 2004.

52 Riley-Smith 2009, 61.

53 Stathakopoulos 20062006 ?.

54 Mol 2012, 178.

55 Herrmann 2007.

56 Pospieszna and Pospieszny 2014, 228-229.

57 Gilchrist 1995, 62-105.

${ }^{58}$ Carraz 2014, 131.

59 Pluskowski 2013, 152-153.

60 Gilchrist 1992.

61 Gilchrist 1995, 93.

62 Piana and Carlsson 2014.

${ }^{63}$ Carraz 2014, 130.

${ }^{64}$ Vairo 2014, 217.

${ }^{65}$ Wilson 2010; Jansen 2010.

66 Nicholson 2010.

${ }^{67}$ Brenot et al 2013.

68 Lord 2002, 240-244.

${ }^{69}$ Mayes 2002.

70 Laszlovszky 2001.

${ }^{71}$ Atzbach 2009.

72 Carlsson 2006.

73 Brus 2004.

${ }^{74}$ Carraz 2008.

75 Gilmour-Bryson 2008.

${ }^{76}$ Nicholson 2006, 87.

77 Jankrift 2006; Marcombe 2006.

${ }^{78}$ Eg Pechuro et al 20112011 ?.

79 Pospieszny 2002.

${ }^{80}$ Wilson 2010.

${ }^{81}$ Major 2013.

82 Vairo 2014, 194.

83 Burgtorf 2008, 4-5.

${ }^{84}$ Major 2015.

${ }^{85}$ Major and El-Ajji 2011, 265-268. 
${ }^{86}$ See Boas and Khamisy 2017.

${ }^{87}$ Morton 2009, 118-133, 166-167.

88 Ioniţă et al 2004.

89 Pluskowski 2013, 97-98.

90 Herrmann 2007, 81; Ose 2002, 25-26.

${ }^{91}$ Vairo 2014.

${ }^{92}$ Gancewski 2001, 16.

${ }^{93}$ Summarised in Pluskowski 2013, 152 -156.

94 Pluskowski 2017.

${ }^{95}$ Kola 2002.

${ }^{96}$ See papers on rural and urban churches in Pospieszna 2010.

97 Schenk 2012, 207.

98 Carraz 2014, 130.

${ }^{99}$ Carraz 2013b, 119.

100 Vairo 2014, 193.

101 Carraz 2014.

102 Vairo 2014.

103 Gilchrist 1995.

104 Zeebroek et al 2006.

105 See Pluskowski 2017.

106 Apals 1996.

107 Carraz 2014, 125, 129.

108 Vairo 2014, 217.

109 Gerrard 1999, 148.

110 Pereira 2003.

111 Pluskowski 2010, 205.

112 Grupa and Kozłowski 2009.

113 Jurkowlaniec 2010.

114 Kasdagli 2008.

115 Gilchrist 2009.

116 Sarnowsky 2011, 10.

117 Paszkiewicz 2009.

118 Dygo 1989, 69.

119 Miehle 1998.

120 Urban 1993; Haljak 2010, 101-109.

121 Metcalf 1995, 296.

122 Kasdagli 2013, 207.

${ }^{123}$ Whatley 2012.

124 Borchardt 2016, 122.

125 Poliński 2003.

126 Pluskowski 2017.

127 Gerrard 1999.

128 See note 47.

129 Khamisy 2013.

130 O'Malley 2013, 227. 
131 Tyerman 2013, 957.

132 Carraz 2013b, 118.

133 Paravicini 1989.

134 Forey 2002, 6-7.

135 Fonseca 2016.

136 Dutra 1970, 5.

137 Pluskowski 2017.

138 Burgtorf 2008, 2-3.

139 Carraz 2014, 107.

140 Baigent et al 1982.

141 Eco 1989, 67. 